\title{
SELF ESTEEM PADA ANAK USIA SEKOLAH DASAR UNTUK PENCEGAHAN KASUS BULLYING
}

\author{
Dian Fitri Nur Aini \\ Universitas Muhammadiyah Malang \\ e-mail:Dian.fnai@gmail.com
}

\begin{abstract}
Primary school age is an early phase of development to enter the world of formal education. At that age phase the child undergoes a transformation from knowing some individuals and the environment to an environment that has a more complex member of the school environment. The school environment has some common problems. Bullying is one of the problems that occur in children in the school environment. The impact of bullying can affect all aspects of the child physically and psychologically. Bullying cases can be handled using several methods tailored to the content of the problem. Self esteem optimization is one way that can be applied to prevent cases of bullying in elementary school age children.

Self esteem needs is one of the needs that can not be ignored in a child's life. The need for a good self-esteem for the child can increase his confidence. The support and involvement of family and school environments is needed to achieve self esteem needs. Good coordination of the family and school environment to support the improvement of self esteem can create children with good self-concept so as to overcome various problems of bullying originating from the environment.
\end{abstract}

Keywords: Self esteem, elementary school children, bullying.

\begin{abstract}
Abstrak: Usia sekolah dasar merupakan fase perkembangan awal untuk memasuki dunia pendidikan formal. Pada fase usia tersebut anak mengalami transformasi dari mengenal beberapa individu dan lingkungan menuju lingkungan yang memiliki anggota yang lebih kompleks yaitu lingkungan sekolah. Lingkungan sekolah memiliki beberapa permasalahan yang umumnya terjadi. Bullying adalah salah satu permasalahan yang terjadi pada anak di lingkungan sekolah. Dampak yang ditimbulkan dari bullying dapat mempengaruhi seluruh aspek dalam diri anak baik fisik maupun psikologis. Kasus bullying dapat ditangani dengan menggunakan beberapa metode yang disesuaikan dengan konten permasalahannya. Optimalisasi self esteem merupakan salah satu cara yang dapat diterapkan untuk mencegah kasus bullying pada anak usia sekolah dasar.

Self esteem needs merupakan salah satu kebutuhan yang tidak dapat diabaikan dalam kehidupan anak. Kebutuhan penghargaan diri yang baik terhadap diri anak dapat meningkatkan kepercayaan dirinya. Dukungan dan keterlibatan lingkungan keluarga dan sekolah sangat dibutuhkan untuk mencapai kebutuhan self esteem. Koordinasi yang baik dari lingkungan keluarga dan sekolah untuk mendukung peningkatan self esteem dapat menciptakan anak dengan konsep diri yang baik sehingga dapat mengatasi berbagai masalah bullying yang berasal dari lingkungannya.
\end{abstract}

Kata kunci: Self esteem, anak usia Sekolah Dasar, bullying

\section{PENDAHULUAN}

Pendidikan

merupakan

serangkaian usaha yang dilakukan oleh individu untuk berproses menuju pengalaman hidup yang lebih baik. Manusia senatiasa berkembang baik dari segi fisik, mental dan spiritual.
Untuk mendukung perkembangan tersebut, serangkaian usaha dilakukan agar mencapai tujuan yang diinginkan. Pendidikan merupakan serangkaian usaha yang digunakan untuk mendukung kerberlangsungan proses tersebut. Pendidikan pertama dimulai 
dari Sekolah Dasar pada masa anak berusia 6-7 tahun. Pendidikan dasar merupakan pondasi untuk membentuk anak menuju kepribadian yang baik di tahap perkembangan selanjutnya.

Usia Sekolah Dasar merupakan jenjang pendidikan yang merupakan lanjutan dari pendidikan kanak-kanak. Pendidikan yang didapatkan pada jenjang pendidikan kanak-kanak secara langsung berpengaruh pada pendidikan di Sekolah Dasar. Aspek perkembangan yang menjadi sorotan pada masa usia Sekolah Dasar lebih difokuskan pada kemampuan kognitif dan psikomotorik anak. Hal ini dikarenakan pada usia perkembangan tersebut anak lebih banyak melakukan aktivitas yang berkaitan dengan proses berfikir dan pergerakan aktif yang mereka lakuka setiap hari. Pada fase masa perkembangan usia Sekolah Dasar, anak mulai memasuki usia sekolah formal. Terdapat beberapa perbedaan kondisi yang dialami anak pada saat masa usia sekolah formal dan masa sebelumnya. Pada masa memasuki usia sekolah formal, anak akan menemui dan berada pada lingkungan baru.

Lingkungan baru yang lebih kompleks ditemui anak seiring dengan bertambahnya usia. Lingkungan baru memiliki banyak individu yang belum dikenal anak pada lingkungan sebelumnya, misalnya guru dan teman yang berbeda. Selain itu, kondisi hubungan pertemanan antara sekolah informal dan formal seperti di Sekolah Dasar juga mengalami perbedaan. Beberapa perbedaan yang muncul mengakibatkan anak harus beradaptasi dengan lingkungan baru tersebut. Di lingkungan baru tersebut, anak menjumpai lebih banyak individu baru seperti guru dan teman. Individu baru yang ditemui anak tersebut terdapat beberapa yang tidak mendukung perkembangan anak. Dari segi pertemanan, terdapat beberapa individu yang tidak saling suka dengan kehadiran teman atau hal lain yang mengakibatkannya sehingga muncul kejadian bullying. Pada umumnya korban bullying terjadi pada anak yang lemah, pemalu, pendiam dan special (cacat, tertutup, pandai, cantik, atau punya ciri tubuh tertentu), yang dapat menajdi bahan ejekan (Astuti, 2008).

Kasus bullying mulai merajalela di Indonesia dari tingkat Sekolah Dasar hingga perguruan tinggi. Menurut survey KPAI, terdapat 369 pengaduan terkait masalah bullying dari kurun waktu 2011 sampai 2014. Kasus bullying yang merupakan salah satu kasus kekerasan di sekolah merupakan kasus dengan angka terbesar dibandingan dengan tawuran pelajar, diskriminasi pendidikan, atau aduan pungutan liar. Menurut ICRW (International Center for Research on Women) pada tahun 2015 terdapat 84\% anak di Indonesia mengalami kekerasan di sekolah. Angka tersebut merupakan angka yang lebih tinggi dari tren di kawasan Asia.

Penanganan kasus bullying dapat dilakukan dengan pencegahan yang dimulai dari diri anak tersebut dan lingkungan anak. Salah satu penanganan pencegahan yang berasal dari diri anak sendiri yaitu dengan peningkatan penghargaan diri anak atau disebut dengan self esteem. Peningkatan self esteem dapat dilakukan dengan peningkatan beberapa komponen self esteem, misalnya feeling of belonging, feeling of competence dan feeling of worth. Selain itu, peran guru dan orang tua juga sangat menentukan dalam peningkatan self esteem anak untuk pencegahan kasus bullying. 


\section{PEMBAHASAN}

\section{PENGERTIAN BULLYING}

Perkembangan

ilmu

pengetahuan dan teknologi semakin pesat dan menyeluruh. Pesatnya perkembangan IPTEK mengakibatkan dampak positif dan negatif. Dampak positif yang ditimbulkan salah satunya adalah akses internet yang terjangkau mengakibatkan pencarian informasi menjadi lebih mudah. Namun kemudahan pencarian informasi tersebut apabila tidak didukung dengan bimbingan orang tua pada anak Sekolah Dasar akan memunculkan tindakan yang negatif. Anak Sekolah Dasar memiliki kecenderungan untuk cepat meniru sesuatu yang baru didapatkannya. Kegiatan meniru yang berdampak negatif salah satunya adalah bullying.

Menurut Coloroso (2007), bullying merupakan tindakan intimidasi yang dilakukan secara berulang-ulang oleh pihak yang lebih kuat terhadap pihak yang lebih lemah, dilakukan dengan sengaja dan bertujuan untuk melukai korbannya secara fisik maupun emosional. Rigby (dalam Astuti, 2008), menyatakan bullying merupakan perilaku agresi yang dilakukan secara berulang-ulang dan terus menerus, terdapat kekuatan yang tidak seimbang antara pelaku dan korbannya, serta bertujuan untuk menyakiti dan menimbulkan perasaan tertekan bagi korbannya.

Bullying (penidasan) merupakan angka yang signifikan di dalam kehidupan siswa (Santrock, 2001). Dalam tindakan bullying terdapat perilaku agresif (Rigby, 2004). Olweus (Krahe, 2005) mendefenisikan bullying adalah perilaku negatif seseorang atau lebih kepada korban bullying yang dilakukan secara berulang-ulang dan terjadi dari waktu ke waktu. Selain itu bullying juga melibatkan kekuatan dan kekuasaan yang tidak seimbang, sehingga korban berada dalam keadaan tidak mampu mempertahankan diri secara efektif untuk melawan tindakan negatif yang diterimanya (Krahe, 2005).

Perilaku bullying menimbulkan dampak yang negatif bagi korbannya. Perilaku negatif tersebut memiliki karakteristik atau ciri-ciri yang menonjol yang ditunjukkan dengan beberapa kondisi. Kondisi yang ditunjukkan menimbulkan dampak yang merugikan baik secara fisik atau mental bagi korban.

Menurut American Psychiatric Association (APA) (dalam Stein dkk, 2006), bullying adalah perilaku agresif yang dikarakteristikkan dengan tiga kondisi yaitu (a) perilaku negatif yang bertujuan untuk merusak atau membahayakan (b) perilaku yang diulang selama jangka waktu tertentu (c) adanya ketidakseimbangan kekuatan atau kekuasaan dari pihak-pihak yang terlibat. Beberapa kondisi tersebut lebih mengacu kearah yang dapat menjadikan korban trauma, cemas dan sikap-sikap lain yang tidak nyaman.

Perilaku bullying memiliki kesamaan dengan agresif yaitu melakukan tindakan penyerangan kepada orang lain. Perbedaan terletak pada jangka waktu dilakukannya tindakan tersebut. Bullying mengacu pada tindakan penyerangan kepada orang lain dengan jangka waktu yang berulang sehingga mengakibatkan korban bullying merasa cemas dan terintimidasi (Krahe, 2005). Sedangkan tindakan agresif jangka waktu dilakukan hanya sekali.

Perilaku bullying dapat dilakukan secara verbal dan nonverbal. Perilaku bullying secara verbal dilakukan dengan mengeluarkan katakata yang tidak baik kepada korban. Bullying secara nonverbal dilakukan 
dengan tindakan yang berkaitan dengan melukai fisik korban.

Field (2007) membagi tipe-tipe tindakan bullying menjadi teasing (sindiran), exclusion (pengeluaran), physical (fisik) dan harassment (gangguan). Teasing (sindiran) merupakan perilaku mengejek, menghina, melecehkan, meneriaki, mengganggu korban melalui alat komunikasi. Exclusion (pengeluaran) berkaitan dengan mengucilkan korban secara sosial seperti mengeluarkan korban dari grup teman sebaya, tidak mengikutsertakan korban dalam percakapan, dan tidak mengikutsertakan korban dalam permainan. Physical (fisik) seperti memukul, menendang, menjambak, mendorong, mengganggu dan merusak barang milik korban. Harassment (gangguan) berkaitan dengan pernyataan yang bersifat mengganggu dan menyerang tentang masalah seksual, jenis kelamin, ras, agama, dan kebangsaan.

Dari berbagai kajian istilah di atas dapat disimpulkan pengertian dari bullying adalah suatu perilaku negatif yang dilakukan secara berulang-ulang, dilakukan dengan sadar dan sengaja yang bertujuan untuk menyakiti orang lain secara fisik maupun emosional, dilakukan oleh individu atau kelompok dan terdapat ketidakseimbangan kekuatan atau kekuasaan dari pihakpihak yang terlibat. Perilaku bullying menimbulkan dampak yang merugikan bagi korban bullying. Korban bullying membutuhkan dukungan serta perlindungan dari individu dewasa yang berada di lingkungan anak, misalnya guru, orangtua atau saudara.

\section{PENGERTIAN SELF ESTEEM}

Manusia memiliki kecenderungan untuk berproses menjadi manusia yang lebih baik. Dorongan untuk menuju arah lebih baik tersebut dipengaruhi oleh motivasi yang muncul dalam diri individu. Perkembangan motivasi dapat dipengaruhi oleh beberapa pemenuhan kebutuhankebutuhan. Pemenuhan kebutuhan terdiri dari kebutuhan dasar yang disebut dengan kebutuhan fisiologis. Selain itu terdapat kebutuhan perkembangan atau disebut dengan defisiensi. Salah satu bagian dari kebutuhan defisiensi adalah kebutuhan harga diri atau self esteem.

$$
\text { Self esteem merupakan }
$$

kebutuhan yang dapat dipenuhi setelah kebutuhan fisiologis (makan, tidur, dll), kebutuhan rasa aman, dan kebutuhan kasih sayang (Maslow dalam Scunk, et. al, 2012). Kebutuhan self esteem terpenuhi sebelum kebutuhan tertinggi dalam diagram kebutuhan maslow yaitu kebutuhan aktualisasi diri. Kebutuhan self esteem merupakan kebutuhan untuk dapat menunjang kebutuhan tertinggi dalam kehidupan manusia yaitu aktualisasi diri.

Self esteem berkaitan dengan keadaan diri manusia dalam membentuk dirinya. Self esteem menurut Frey \& Curlock dalam adalah Emanza (2008) merupakan evaluasi pribadi terhadap diri dan perasaan berharga yang terkait dengan konsep diri. Perasaan berharga yang dimiliki individu muncul dari dukungan lingkungan sehari-harinya. Lingkungan anak terdiri dari lingkungan keluarga dan lingkungan sekolah. Peran orang tua dari lingkungan keluarga serta peran guru dari lingkungan sekolah menjadi pendukung utama dalam proses pemenuhan harga diri atau self esteem anak.

Harter dalam Papalia (2009) mengatakan bahwa harga diri pada masa kanak-kanak awal cenderung bersifat semua atau tidak sama sekali; 'saya baik' atau 'saya jahat'. Pada masa kanak-kanak tengah, evaluasi personal 
mengenai kompetensi dan kemampuan berdasarkan internalisasi standar orangtua atau sosial anak menjadi hal penting dalam membentuk atau mempertahankan perasaan keberhargaan diri.

Rogers (dalam Musbikin, 2014) membagi konsep diri menjadi tiga bagian, yaitu: (1) ideal self, (2) self image, dan (3) self esteem. Self image atau citra diri adalah persepsi kita terhadap diri kita. Sedangkan penilaian terhadap diri kita, baik-buruk, pintarbodoh, disebut self esteem. Orang yang memiliki self esteem yang optimal disebut ideal self atau diri yang ideal. Tinggi rendahnya self esteem tergantung pada jarak antara diri yang ideal (ideal self) dan citra diri (self image).

Dari beberapa penjelasan tersebut, dapat disimpulkan bahwa pengertian self esteem adalah penilaian individu terhadap kehormatan diri, melalui sikap terhadap dirinya sendiri yang bersifat implisit dan tidak diucapkan secara verbal serta menggambarkan bagaimana individu menilai dirinya sendiri sebagai individu yang memiliki kemampuan, berharga dan berkompeten. Self esteem dapat memperkuat citra diri individu sehingga berdampak pada meningkatkan perasaan percaya dan yakin terhadap kemampuan diri yang dimilikinya.

\section{KOMPONEN SELF ESTEEM}

Menurut Felker (dalam Hastuti, 2016), komponen harga diri meliputi feeling of belonging, yaitu perasaan individu bahwa dirinya merupakan bagian dari suatu kelompok dan individu tersebut diterima oleh anggota kelompok lainnya. Individu akan memiliki penilaian yang positif akan dirinya apabila individu tersebut merasa diterima dan menjadi bagian dari kelompok tersebut. Individu akan menilai sebaliknya apabila merasa ditolak atau tidak diterima oleh kelompok tersebut.

Komponen selanjutnya adalah feeling of competence, yaitu perasaan individu bahwa mampu melakukan sesuatu untuk mencapai hasil yang diharapkan. Apabila individu berhasil mencapai tujuan akan memberikan penilaian positif terhadap dirinya. Selain itu, individu merasa percaya terhadap pikiran, perasaan dan tingkah laku yang berhubungan dengan kehidupannya. Komponen terakhir adalah feeling of worth, yaitu perasaan individu bahwa dirinya berharga. Individu yang memiliki perasaan berharga akan menilai dirinya secara positif, merasa yakin terhadap diri sendiri, dan mempunyai harga diri atau self respect.

Dari beberapa kajian tersebut dapat disimpulkan bahwa self esteem memiliki beberapa komponen yang terdiri dari feeling belonging, feeling competence, dan feeling worth. Ketiga komponen self esteem merupakan hal yang saling berhubungan dan akan menjadikan individu yang memiliki self esteem yang positif apabila mampu terpenuhi komponen-komponen tersebut.

\section{KARAKTERISTIK INDIVIDU BERDASARKAN SELF ESTEEM}

Manusia memiliki beberapa ciri yang berkaitan dengan self esteem dapat dilihat secara langsung maupun tidak langsung. Individu dibedakan menjadi dua yaitu individu dengan self esteem yang tinggi dan self esteem yang rendah.

Coopersmith (dalam Emanza, 2008: 10) membagi tingkat self esteem individu menjadi dua golongan yaitu individu dengan harga diri yang tinggi dan rendah. Individu dengan harga diri yang tinggi memiliki beberapa 
karakteristik yaitu memiliki sikap aktif dan mampu mengekspresikan diri dengan baik, memiliki prestasi dalam bidang akademik dan mampu menjalin hubungan sosial, dapat menerima kritik dengan baik, percaya terhadap persepsi diri, memiliki keyakinan diri berdasarkan kemampuan yang dimilikinya, tidak terpaku hanya pada kesulitan yang dihadapi, tidak mudah terpengaruh dengan penilaian orang lain terhadap dirinya, mampu menyesuaikan diri dengan lingkungan baru sehingga mudah beradaptasi.

Selain itu, Coopersmith menjelaskan karakteristik individu dengan harga diri yang rendah yaitu memiliki perasaan inferior (merasa kurang sempurna), takut gagal dalam membina hubungan sosial, sering putus asa dan depresi, merasa diasingkan dan tidak diperhatikan, kurang mampu mengekspresikan diri, tidak konsisten, pasif mengikuti lingkungan, mudah mengakui kesalahan, menggunakan banyak taktik mempertahankan diri (defense mechanism).

Berdasarkan beberapa kajian terkait dengan karakteristik individu berdasarkan self esteem dapat disimpulkan bahwa karakteristik self esteem dapat dilihat secara langsung dan tidak langsung. Untuk membedakan individu dengan self esteem tinggi dan rendah memerlukan waktu serta proses yang tidak pendek.

\section{KARAKTERISTIK SEKOLAH DASAR}

SISWA

Usia sekolah dasar dimulai sejak anak berusia 6 tahun sampai usia kurang lebih 12 tahun. Berdasarkan pembagian tahapan perkembangan anak, ada dua masa perkembangan pada anak usia sekolah, yaitu pada usia 6-9 tahun atau masa kanak-kanak tengah dan pada usia 10-12 tahun atau masa kanak-kanak akhir. Setelah menjalani masa kanak-kanak akhir, anak akan memasuki masa remaja.

Pada usia sekolah, anak memiliki karakteristik yang berbeda dengan anakanak yang usianya lebih muda. Perbedaan ini terlihat dari aspek fisik, mental-intelektual, dan sosial-emosial anak (Papalia, et. al, 2009). Pertumbuhan fisik pada anak usia sekolah tidak secepat pada masa sebelumnya. Anak akan mengalami pertumbuhan tinggi badan antara 5-6 $\mathrm{cm}$ setiap tahunnya. Pada masa ini, terdapat perbedaan antara anak perempuan dan anak laki-laki. Namun, pada usia 10 tahun ke atas pertumbuhan anak laki-laki akan menyusul ketertinggalan mereka. Perbedaan lain yang akan terlihat pada aspek fisik antara anak laki-laki dan perempuan adalah pada bentuk otot yang dimiliki. Anak laki-laki lebih berotot dibandingkan anak perempuan yang memiliki otot lentur.

Ciri khas kehidupan sosialemosional anak usia sekolah adalah menghabiskan waktu dengan lingkungan sekolah dan temantemannya. Anak membutuhkan lingkungan yang lebih luas dan bergaul dengan lebih banyak orang. Pada masa ini anak cenderung memiliki keinginan yang sangat besar untuk diterima menjadi bagian dari kelompok serta membentuk kelompok-kelompok, masa sekolah disebut juga masa gang age (Vasta, et. al, 2004). Ciri-ciri anak sekolah dalam kegiatan berkelompoknya terlihat dari cara-cara mereka menggunakan istilah-istilah dalam kelompok mereka. Walaupun demikian, anak tetap mengharapkan kedekatan dengan orang tua meskipun dengan bentuk yang berbeda denagan anak yang usianya lebih muda.

Erikson (dalam Santrock, 2011) menjelaskan anak usia Sekolah Dasar berada pada tahap industry vs inferiority 
yang pada tahap ini anak sudah memasuki dunia sekolah. Pada tahap ini dapat dikatakan anak memiliki jiwa kompetitif yang tinggi dan berfokus pada pencapaian prestasi dan anak akan berusaha semaksimal mungkin agar dapat lebih unggul dibanding temantemannya. Jiwa kompetitif pada anak menurut Rigby (2007) dapat menimbulkan adanya tindakan bullying pemenang dalam suatu kegiatan kompetitif sering kali memunculkan sikap arogansinya dengan menindas temannya yang kurang mampu.

Berdasarkan beberapa kajian dapat disimpulkan bahwa karakteristik siswa usia sekolah dasar merupakan usia yang potensial dalam perkembangan pada seluruh aspek baik kognitif, afektif dan psikomoriknya. Perkembangan moral pada usai Sekolah Dasar menjadi kekhususan dalam masa ini. Anak mulai belajar mengerti nilai dan memegang aturan yang ditetapkan baik dari lingkungan keluarga, sekolah dan lingkungan sosialnya. Selain itu, pada perkembangan usia Sekolah Dasar anak mengedepankan kemampuan kognisi yang berdampak pada meningkatnya jiwa kompetitif anak sehingga mudah memunculkan tindakan bullying terhadap teman yang kurang mampu dalam aspek kognisi atau yang lain.

\section{FAKTOR-FAKTOR \\ YANG MEMPENGARUHI SELF ESTEEM}

Self esteem merupakan persepsi diri individu terhadap konsep dirinya. Dukungan untuk peningkatan self esteem berasal dari diri individu dan dari luar individu yaitu lingkungan dan individu yang berada di lingkungannya. Selain dukungan, peningkatan atau penurunan self estem dipengaruhi oleh beberapa faktor, yaitu jenis kelamin, kelas sosial dan lingkungan (Simmons dalam Emanza, 2008).
Perbedaan jenis kelamin mempengaruhi cara pandang individu terhadap dirinya (Simmons dalam Emanza, 2008). Anak perempuan lebih sensitif terhadap dirinya, merasa khawatir dengan kemampuannya, dan peka terhadap penilaian orang lain dibandingkan dengan anak laki-laki. Hal ini terjadi karena anak perempuan lebih peduli dengan self esteem agar dapat diterima dalam lingkungannya.

Selain itu kelas sosial juga menjadi faktor yang mempengaruhi self esteem. Kelas sosial terkait dengan pekerjaan, pendidikan, dan penghasilan orang tua sangat menentukan penerimaan anak di lingkungannya. Anak dengan kelas sosial rendah cenderung menjadi korban bully oleh teman dengan kelas sosial menengah dan atas.

Lingkungan juga menjadi faktor terakhir yang menentukan self esteem anak. Lingkungan berhubungan dengan perkembangan self esteem individu. Lingkungan yang dimaksudkan adalah lingkungan rumah dan sekolah. Anak dengan lingkungan rumah serta dukungan orang tua yang baik akan berpengaruh pada self esteem anak yang tinggi. Lingkungan sekolah yang mendukung peningkatan juga sangat berpengaruh terhadap self esteem anak. Anak di lingkungan sekolah yang tidak kondusif serta peran guru yang tidak maksimal mengakibatkan anak memiliki self eteem yang rendah dan cenderung kurang mampu mengekspresikan diri.

Dari beberapa kajian di atas, dapat disimpulkan bahwa faktor-faktor yang mempengaruhi self esteem adalah jenis kelamin, kelas sosial dan lingkungan. Beberapa faktor tersebut saling berhubungan dan menentukan. 


\section{STRATEGI MENGEMBANGKAN SELF ESTEEM ANAK}

Di Era globalisai, secara umum anak tumbuh dan berkembang dengan pujian yang kosong. Hal ini berdampak pada kecenderungan anak memiliki self esteem yang semu. Anak cenderung menerima pujian untuk sesuatu yang dilakukannya tanpa usaha dan hasil yang kurang memuaskan. Hal ini berdampak pada menurunnya tingkat kompetensi dan penerimaan kritik. Menurut Santrock (2011) menyatakan beberapa cara yang baik untuk meningkatkan harga diri anak yaitu: (1) identifikasi domain kompetensi yang dianggap penting bagi anak, (2) dukungan emosional dan persetujuan sosial, (3) prestasi, (4) coping.

Harter dalam Santrock (2011) menyatakan percaya bahwa intervensi harus diberikan pada penyebab harga diri. Anak akan memiliki self esteem tertinggi pada saat mampu tampil dengan kompeten di domain yang dianggap penting baginya. Anak harus didorong untuk mengidentifikasi dan menghargai kemampuan yang dimilikinya. Selain itu, dukungan emosional dan persetujuan sosial juga merupakan hal yang dapat mempengaruhi self esteem anak. Anak dengan self esteem rendah cenderung berasal dari keluarga bermasalah atau ditelantarkan sehingga tidak memperoleh dukungan emosional.

Santrock (2011) menyatkan bahwa self esteem meningkat dengan adanya masalah dan usaha yang dilakukan untuk mengatasi masalah tersebut. Menurut Branden (2005) terdapat dua aspek yang dapat menghambat perkembangan harga diri, yaitu perasaan takut dan perasaan bersalah. Perasaan takut muncul pada saaat anak tidak mampu menghadapi fakta-fakta kehidupan dengan penuh keberanian. Fakta-fakta tersebut merupakan tanggapan negatif terhadap diri yang menjadikan anak hidup dalam ketakutan.

Aspek kedua yang menghambat harga diri adalah perasaan bersalah yang mencakup perasaan bersalah karena melanggar nilai-nilai moral. Anak menghayati kesalahan sebagai sebuah pelanggaran terhadap nilai kehidupan yang telah ditanamkan dalam diri oleh orang yang menguasainya, yaitu seseorang yang dianggap berharga dan ditakuti. Kontrol emosi negatif yang muncul merupakan salah satu aspek perkembangan emosional pada anak. Secara bertahap, anak anak belajar tentang sesuatu yang membuat takut, bersalah, marah, atau sedih, dan bentuk reaksi orang lain dalam menunjukkan emosi ini selanjutnya anak-anak mengadaptasikan perilaku mereka dengan emosi-emosi tersebut.

Dari beberapa kajian di atas, dapat disimpulkan bahwa strategi yang dilakukan untuk peningkatan self esteem anak adalah mengkondisikan anak bersikap positif dalam empat kondisi yaitu (1) Rasa Terikat; anak merasa adanya kepuasan bathin dalam hubungannya dengan orang tua dan keluarganya sehingga menimbulkan rasa keterikatan, (2) Rasa Unik; anak merasa dirinya spesial. Anak menghargai sifat tertentu yang membuatnya istimewa ketika mampu menerima penghargaan atau pengakuan dari orang lain, (3) Rasa berkuasa; perasaan yang bersumber dari memiliki sumber daya dan kemampuan untuk mempengaruhi lungkungannya,

Model; contoh perilaku individu, falsafah, dan tindakan yang menjadi model untuk mewujudkan nilai-nilai, cita-cita dan tolok ukur pribadi. Untuk membuat harga diri tinggi, keempat kondisi tersebut harus hadir secara terus menerus. Apabila salah satu kondisi itu 
tidak cukup tersedia maka akan berakibat gangguan terhadap harga diri.

SELF ESTEEM PADA ANAK USIA SEKOLAH DASAR UNTUK PENCEGAHAN KASUS BULLYING

Pengembangan self esteem dipengaruhi oleh pengalaman pada masa awal kanak-kanak. Proses sosialisasi dilakukan oleh keluarga sebagai tempat pendidikan pertama. Kepribadian anak dipengaruhi oleh pendidikan yang didapatkan pada awal anak tersebut mulai tumbuh. Orang tua sebagai role model (contoh) anak harus mampu memberikan contoh yang baik kepada anak. Pemberian contoh dapat dilakukan setiap hari sehingga akan menjadi kebiasaan.

Orang tua dengan self esteem tinggi cnderung memiliki anak dengan self esteem yang tinggi. Orangtua yang demokratis cenderung membentuk harga diri anak menjadi tinggi, sementara orang tua yang otoriter dan permisif cenderung membentuk harga diri anak menjadi rendah. Marzuki (2004) berpendapat bahwa orangtua atau pendidik harus memberikan respon positif kepada anak, yang ditunjukkan dengan sikap, perhatian, serta mendengarkan secara aktif terhadap apa yang dikemukakan oleh anak. Orang tua harus bersikap perhatian dan menganggap anak sebagai individu yang harus didengarkan pendapatnya.

$$
\text { Self esteem bisa dibangun }
$$

melalui proses pendisiplinan anak dengan syarat bahwa anak merasa dicintai tanpa syarat. Ariesandi (2008) mengemukakan beberapa cara meningkatkan self esteem anak yaitu dengan memberikan teladan pada anak melalui tindakan orangtua, memperhatikan usia dan perkembangan anak, menggunakan bahasa cinta anak untuk memenuhi tangki emosionalnya, melakukan komunikasi dengan memperhatikan tipe kepribadian anak, serta memahami mekanisme pikiran anak.

Self esteem berkaitan dengan perasaan bangga dari anak sebagai hasil dari belajar mengerjakan sesuatu atas usahanya sendiri (Yustinus, 2006). Pada tingkatan ini, anak ingin membuat benda-benda, menyelidiki dan memuaskan rasa ingin tahunya tentang lingkungan, memanipulasi, dan mengubah lingkungan tersebut. Anak yang berusia dua tahun yang bersifat ingin tahu dan agresif dapat menjadi sangat destruktif karena dorongan untuk memanipulasi dan menyelidiki ini menguasai dirinya. Orang tua harus memfasilitasi kebutuhan anak tersebut sehingga perasaan dihina dan tidak dihargai tidak muncul.

Berdasarkan beberapa kajian tersebut dapat disimpulkan bahwa self esteem pada usia sekolah dasar untuk pencegahan kasus bullying dapat dilakukan dengan peningkatan mutu perilaku dan performa tinggi dari orangtua, orang tua menerapkan batasbatas yang jelas mana perilaku yang boleh dan mana yang tidak dilakukan, orang tua melakukan bimbingan perilaku dan umpan balik, memperlakukan anak dengan respek dan kepercayaan diri, memberi perhatian dan terlibat dalam kegiatan akademik dan sosial anak, pendekatan yang tidak memaksa untuk membentuk disiplin anak, memperlakukan anak secara demokratis

\section{SIMPULAN}

Bullying merupakan kasus yang sedang marak dan sangat merugikan korbannya. Bullying dapat menyebabkan dampak negatif baik berupa kerugiaan fisik dan mental. Untuk mencegah kasus bullying yang merugikan tersebut, dapat dilakukan dengan peningkatan self esteem pada diri siswa Sekolah Dasar yang menonjol 
dengan jiwa kompetitifnya pada usia tersebut. Self esteem pada indivisu memiliki karakteristik tertetu yaitu individu dengan self esteem tinggi dan self esteem rendah. Selain itu, self esteem juga dipengaruhi oleh beberapa faktor yaitu jenis kelamin, kelas sosial dan lingkungan. Strategi untuk meningkatkan self esteem dapat dilakukan dengan beberapa cara yang dilakukan oleh orang tua sebagai individu yang berasal dari lingkungan pertama siswa yaitu rumah dan lingkungan sekolah yang dilakukan oleh guru.

Self esteem pada usia sekolah dasar untuk pencegahan kasus bullying dapat dilakukan dengan peningkatan mutu perilaku dan performa tinggi dari orangtua, orang tua menerapkan batasbatas yang jelas mana perilaku yang boleh dan mana yang tidak dilakukan, orang tua melakukan bimbingan perilaku dan umpan balik, memperlakukan anak dengan respek dan kepercayaan diri, memberi perhatian dan terlibat dalam kegiatan akademik dan sosial anak, pendekatan yang tidak memaksa untuk membentuk disiplin anak, memperlakukan anak secara demokratis

Pembentukan self esteem (harga diri) merupakan sebuah proses yang berkesinambungan. Self esteem yang telah terbentuk pada usia dini akan memberikan pengaruh yang sangat signifikan terhadap perilaku kehidupan anak di kemudian hari. Langkahlangkah nyata dan penggunaan strategi yang tepat perlu dilakukan guru dan pihak sekolah dalam rangka menuangkan pengembangan harga diri anak dalam proses pembelajaran. Harus disadari bahwa tumbuhnya perhargaan terhadap diri tidak terlepas dari bagaimana orang lain menghargai diri anak. Sedemikian pentingnya pengembangan harga diri bagi setiap individu, maka perlu adanya kerjasama yang sinergis antara guru di sekolah dan orangtua.

\section{DAFTAR PUSTAKA}

Ariesandi S. 2008. Rahasia Mendidik Anak Agar Sukses dan Bahagia, Jakarta: PT Gramedia Pustaka Utama.

Astuti, P. R. 2008. Meredam Bullying: 3 Cara Efektif Menanggulangi Kekerasan Pada Anak. Jakarta: PT Grasindo

Branden N. 2005. The Power of SelfEsteem. New York: Bantam.
Coloroso.2007. Stop Bullying (Memutus Rantai Kekerasan Anak dari Prasekolah Hingga SMU). Jakarta: Serambi

Coopersmith, S. 1967. The Antecedents of Self Esteem. San Francisco, California: W.H. Freemen and Co.

Emanza, Handayani Gita. 2008. Hubungan Harga Diri dan Citra Tubuh pada Remaja Putri Obesitas Sosial Ekonomi Menengah Atas. Skripsi: Universitas Indonesia.

Field, A. 2008. How to Design and Report an Experiments.London: Sage Publications.

Krahe, Barbara. 2005. Perilaku Agresif, Buku Panduan Psikologi Sosial .Yogyakarta: Pustaka Pelajar

Komisi Perlindungan Anak Indonesia. 2014. KPAI: Kasus Bullying dan Pendidikan Karakter. (http://www.kpai.go.id/berita/kpai -kasus-bullying-dan-pendidikankarakter/)

Marzuki, A. Choiran. 2004. Anak Saleh dalam Asuhan Ibu Muslimah. Yogyakarta: Mitra Pustaka.

Musbikin, Imam. 2004. Mendidik Anak Ala Shinchan. Yogyakarta: Mitra Pustaka. 
Papalia Olds Feldman. 2009. Human Development. Jakarta: Salemba Humanika

Santrock, J. W. 2009. Masa perkembangan anak. Jakarta: Salemba Humanika.

Schunk, D.H., Pintrich, P.R., \& Meece, J.L., 2010. Motivation in Education: Theory, Research, and Applications Third Edition. New Jersey: Pearson Education.

Stein dkk. 2006. Adolescent male bullies, victims, and bully-victims: a comparison of psychosocial and behavioral characteristics. Journal of Pediatric Psychology

Marzuki, A. Choiran. 2004. Anak Saleh dalam Asuhan Ibu Muslimah. Yogyakarta: Mitra Pustaka.
Musbikin, Imam. 2004. Mendidik Anak Ala Shinchan. Yogyakarta: Mitra Pustaka.

Rigby, Ken. 2007. Bullying in schools: and what to do about it. Acer Press: Camberwell Australia.

Vasta, R., Miller. A.S., \& Ellis, S. 2004. Child Psychology. USA: John Wiley \& Sons, Inc.

Yustinus, Semiun. 2006. Kesehatan Mental 2. Yogyakarta: Kanisius 